Милица Шкорић

Универзитет у Београду

Факултет политичких наука

milica95.skoric@gmail.com

DOI: 10.18485/rit.2021.19.36.8
УДК: 322:271.722(620)"19/20"

322:271.723(630)"19/20"

322(635)"19/20"

Прегледни рад

Датум пријема: 27.04.2021

\title{
УЛОГА РЕЛИГИЈЕ У ПОЛИТИЧКИМ ПРОЦЕСИМА ЕГИПТА, ЕРИТРЕЈЕ И ЕТИОПИЈЕ У ХХ И ХХІ ВЕКУ
}

\begin{abstract}
Резиме
Иако је секуларизачија начело већине яржава gанас, на йримеру Еїиӣ̄̄a, Ери-

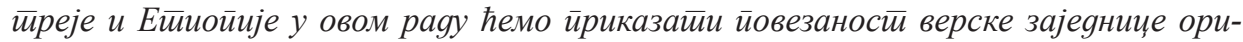
јенйално ирравославних хришћана са властима одабраних држава. Црква је у овим

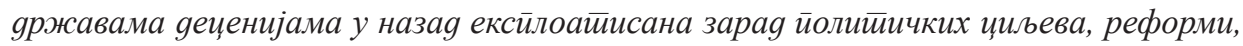

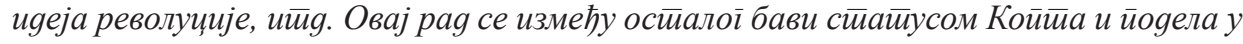

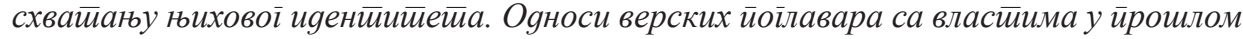

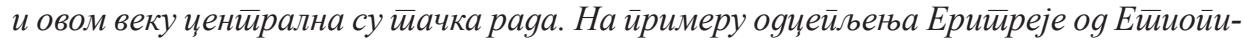
је, које је ирраиило оввајање иркве, иоказало се како је самостилнна ирква у независној яржави значајан елеменй за конитролисање маса и усмеравање ірађана у жеьеном ӣравиу. Великим делом рая се базира на објашњавану ӣолитичке сийуаиије у изабраним државама и месйом иркве у йим иеериоgима. Показало се gа је ирква

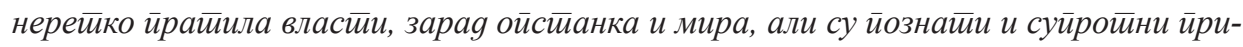

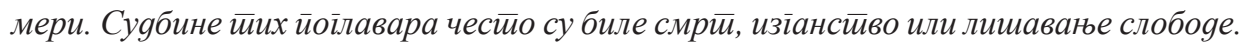

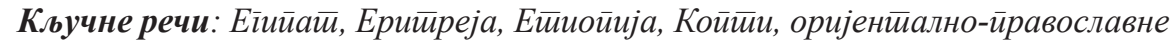

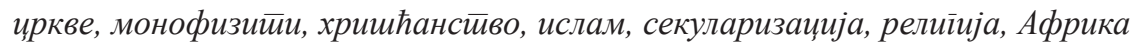

\section{Увод}

Концепт секуларизма је у већем делу савременог света широко усвојен, а многе државе том начелу теже. Чак и у државама које имају званичну религију, њен статус је често ограничен на неки облик формалног признања, са тим што је већи део друштвене улоге религије или верских институција преузела држава (Јевтић, 2009). Принцип одвајања религије од државе више је заступљен у демократским друштвима него у репресивним.

Овај рад представиће три Афричке државе: Египат, у ком је ислам државна религија, Етиопију у којој је већинско становништво хришћанско и 
Еритреју, младу републику још увек недовољно демократизовану. У ове три државе постоји значајан број припадника оријентално-православне цркве који су историјски утицали на политичке процесе.

Оријентално-православне цркве су источне хришћанске цркве које признају прва три васељенска сабора. На четвртом сабору у Халкедони, 451. године дефинисан је став о две природе Христа - божанској и људској (диофизитизам), што је довело до настанка оријентално-православних цркава. Прехалкедонске цркве нису признале одлуке Халкедоског сабора, за њих природа Христа монофизитска, тј. искључиво божанска. Заједници оријентално-православних цркава припадају: Еритрејска, Етиопска, Јерменска, Коптска, Маланкарска и Сиријска оријентално-православна црква.

Државе које ће бити предмет овог рада су вишеверске, тако се на територији данашњег Египта налази неодређен број Копта (6\%-16\%), значајне православне мањине. Приказаћемо у овом раду како је однос врховног поглавара Коптске цркве са властима од суштинског значаја за њихов суживот са муслиманском већином. Однос религије и толеранције посматраћемо на примеру Египта. Колико је систем једне државе везан за конкретно верско учење толико је мање толеранције према припадницима других религија. Посебно је видљиво одсуство толеранције у државама у којима је ислам државна религија, као што је случај у Египту (Јевтић, 2009). На примеру Етиопије уверићемо се да иако су већинско становништво, православци у Етиопији су након комунистичке револуције 1974. године морали да конформирају своје ставове са државним, како би црква опстала. Уједно ће бити приказан утицај државних власти на цркву данас - покушаји да се црква повинује власти су непобитан доказ пресудне улоге коју заузима у Етиопијском друштву. Еритреја, која је 1993.година постала независна држава, до данас је једопартијска република којом већ двадесет и седам година влада Исајас Афеверки (Isaias Afwerki). Број муслимана и хришћања је изједначен, уједно ове две религије су две од четири признате. Верски прогони присталица непризнати, али и признатих верских група су свакодневница Еритреје.

Савремена државе на афричком континенту следиле су сличне обрасце у свом односу према религији (и исламу и хришћанству) - државе се мешају и конфронтирају у покушају да одговоре на питање ко ће владати и како ће управљати државом. Религијске вође имају велики утицај на државу кроз своје везе у друштву, а такође и због чињенице да је религија више укоријењена у друштву у односу на државне институције које су релативно нове и стране (Mekonnen i Kidane, 2014). 


\section{ЕГИПАТ}

Арапска Република Египат је трансконтинентална држава која се већим делом простире на територији североисточној Африке, а мањи део налази се на подручју југозападне Азије. Према најновијим проценама (2020) популација Египта броји 102,33 милиона, што Египат поставља на четрнаесто место у свету по броју становника (World population review, 2020, para.2).

Службена религија у Египту је сунитски ислам ком припада око 90\% становништва. Највећа религијска мањина су Копти, чији тачан број у укупној популацији Египта није утврђен. Процене се крећу између 6\% и $18 \%$ становништва, при чему је египатска влада проценила нижи број, а коптска православна црква три пута већи (Hanna, 2019). Недостатак поузданих демографских података чини све процене неизвесним. Коптска хришћанска популација у Египту највећа је хришћанска заједница на Блиском Истоку и Северној Африци. Процене су да је 95\% хришћна у Египту део Коптске православне цркве у Александрији (United States Department of State, 2008). Поглавар ове цркве - „папа Александрије и патријарх престола Светога Марка“ верски је поглавар око 20 милиона хришћана широм света.

Копти египатског порекла одржавају различит етнички идентитет од муслиманских Египћана, при чему неки од њих одбијају арапски идентитет. Генетски, Копти јесу различита популација, иако су уско повезани са египатским муслиманима, више него са било којом другом етничком групом. Идеје да постоји изразито коптски идентитет и да је упуцћивање на Копте као заједницу веродостојно и смислено, ударају у језгро египатског националног идентитета (Sedra, 2007). У већини извештаја о улози Копта у политичком животу Египта исламисти виде Копте“ као привилеговане госте у муслиманском дому, уживајући у неоправданој попустљивости насталој из секуларизма" (Sedra, 1999: 220 према Ansari, 1984 и др.).

\section{Статус Копта у египатском друштву}

Постоје два главна становишта о статусу Копта у египатском друштву. Први став је став египатског национализма, односно националног јединства. Према овом становишту Копти су саставни део Египта и имају све карактеристике Египћана (Sedra, 1999 према Hanna, 1994). Заговорници „националног јединства““ негирају постојање Коптске мањине унутар египат- 
ских граница, посматрајући Копте као потпуно интегрисане у египатско друштво и не разликујући их од муслимана.

Хана (Hanna Michael Wahid) идентификује седам „стубова“ египатског идентитета - фараонски, грчко - римски, коптски, исламски, арапски, медитерански и афрички - и тврди да су сви Египћани, било да су образовани или неписмени, било да су богати или сиромашни, било коптски или муслимански, носе унутар њих је сваки од стубова „богатство историје Египта“. Хана тврди да је и граница верских обавеза пропустљива - да постоји изразито египатски бренд ислама са „сунитским лицем, шиитском крвљу, коптским срцем и фараонским костима““(Sedra 1999: 222 према Hanna 1994)

Насупрот томе, заговорници супротног становишта дистанцирања Копте од муслимана - не само због различите религије, већ и историје, културе и често расе. Централна тачка овог става јесте инсистирање на „прогону““: „Када се два или више Египћана упознају прва ствар коју сазнају једни о другима јесте ко је хришћанин, а који је муслиман. Све њихове будуће интеракције и односи биће засновани на овом знању“ (Sedra, 1999: 222 према Karas 1985: 97-98). У очима заговорника прогона, јаз између Копта и Муслимана заиста је широк. Према овом стајалишту, Копти су директни потомци старих Египћана, који су од арапске инвазије „Странци у својој земљи“. Сукоб Копта и Муслимана неизбежан, ако узмемо у обзир Кур'анске забране - међу њима је да је „муслиманима забрањено да узимају Јевреје или Хришћане (чак и) као пријатеље“ (Sedra, 1999: 222 према Karas 1985: 93). Заговорници дискурса о прогону указују на пакт Умар, документ из VIII века који је регулисао статус хришћана и јевреја у муслиманским земљама, под којим су били обесхрабрени сви односи између муслимана и Копта; Коптима није било допуштено да се окупљају, држе оружје или врше власт над муслиманима; изградња и обнова цркава била је забрањена; употреба звона, транспарента, књига и крстова код Копта била је смањена. Коначно, заговорници дискурса о прогону тврде да су одредбе Пакта приморале Копте да се одвајају из страха за своју безбедност (Sedra, 1999 према Masriia 1976: 81-83). Заговорници коптског прогона, међутим, сматрају да су арапски муслимани странци на египатском тлу. Према таквим Коптима, њихова историја је од доласка арапских муслимана, „дуга прича о прогонима, масакрима, присилним преображајима, опустошеним и спаљеним црквама”. Копти који су заговорници дискурса прогона, тврде да су угњетавања многострука - низак ниво верске толеранције, именовања у државну службу, политичко представљање, закон о личном статусу, образовање, медији и безбедност. 
Копти немају готово никакву заступљеност на највишим позицијама у јавним предузећима; веома мало их има на високим војним, полицијским, правосудним, обавештајним и дипломатским функцијама, као и у министарствима образовања, спољних послова, информација и унутрашњих послова (Sedra 1999, према al-Gavhari 1996). Коначно, у Горњем Египту владине безбедносне снаге оптужују се да нису пружиле довољну заштиту Коптима од пораста насиља које је погодио је регион крајем 1980-их (Sedra, 1999, према Eibner 1993).

Корени националног јединства и дискурси прогона почињу од XX века. Појава националног идентитета била је извор неизвесности и несигурности за Коптки цркву и заједницу уопште. Средином века сазрели су потомци коптске елите. Њихово образовање на европским универзитетима убедило их је да једино реформама њихова заједница и црква може опстати. У укидању џизије - пореза усмереног на верске мањине 1855. године, видели су корак ка том циљу. Са друге стране, појавом египатског грађанства, припадници поменуте елите схватили су да пређашни систем, под којим муслимани доживљавају Копте као заштићену мањину, никада неће бити довољан да испуни коптске тежње.

Двадесетих година XX века млади Копти постајали су све свеснији своје религије, корена, цркве и баштине своје заједнице. Таква сазнања навела су их да размишљају о себи и свом идентитету у новом светлу. Укратко, открили су славну прошлост и покушали је оживети (Sedra, 1999 према Assad, 1972).

\section{Кирил и Насер}

Папа Коптске цркве је склопио партнерство са председником Гамал Абдел Насером (Gamal Abdel Nasser), у оквиру ког је промовисао лојалност режиму међу коптима. Заузврат, Насер је осигурао сигурност заједнице и статус Папе као легитимног представника копта.

Политике институционализоване током Насерове ере утицале су на равнотежу снага између унутар цркве и на коптску заједницу уопште. Папа Кирил је са Насером поставио камен темељац катедрале Светог Марка и са поносом поновио Насерову изјаву: „Хришћани и муслимани су одувек живели као браћа“ (Sedra, 1999: 225 према Meinardus 1970). Након шестодневног рата 1967.године Кирил је послао представнике цркве у светске и верске центре, како би проширили арапску перспективу сукоба (Sedra, 1999, пре- 
ма Fawzi 1993), што указује на његову приврженост режиму и покушај да копте приближи и уједини са већинским, арапским становништвом Египта.

Насер је својом ауторитативном политиком утицао на јачање улоге цркве као верског и политичког представника Копта. Представљање Коптских интереса у овом периду нашло се у рукама цркве. Иако су Копти били ангажовани у јавном животу нације као грађани са различитим идеолошким, политичким и културним припадностима, улога цркве као представника Копта била је нерпикосновена - верска припадност заузела је стабилно место у идентитету припадника Коптске цркве, остављајући у сенци грађански идентитет.

\section{Шенуда и Садат}

Док је папа Кирил био заговорник дискурса о националном јединству, његов наследник, Папа Шенуда III од Александрије (Pope Shenouda III) био је критичар режима. Избор Шенуда за 117. папу Коптске православне цркве 1971.године означила је крај партнерства државе и коптске цркве. Нови папа је одбио да обећа своју оданост режиму. За успех Шенуда у његовом пркосу држави била је заслужна мобилизација коптске заједнице - нарочито коптске средње класе - која му је пружала највећу подршку.

У јулу 1972. године Скупштина хришћанских цркава у Египту позвала је на окончање дискриминације у случајевима личног статуса, именовања и на укидање ограничења изградњи цркви. Док је тадашњи председник Анвар ел Садат (Anwar el-Sadat) живљавао ислам као политички идиом у Египту - у настојању да уништи корене насеризма међу Египћанима - папа је инсистирао на очувању права Копта. Копти су захтевали од државе: заштиту хришћана и њихове имовине; слободу веровања; прекид одузимања црквене имовине од стране Министарства вакуфа; слободу од узнемиравања у циљу преласка у исламску веру; слобода ширења информација о хришћанским веровањима; одустајање од свих напора да се исламско право примени на немуслимане; већа коптска заступљеност у синдикатима, професионалним удружењима, локалним и регионалним саветима и Народној скупштини (Sedra, 2009 према Samaan и Sukkari 1978). 


\section{Шенуда и Мубарак}

Папа је по доласку Мубарака (Hosni Mubarak) на власт према узору на партнерство који је његов претходник Кирил развио са Насером одлучио да моделира свој однос са новим вођом Египта. Сарађивао је са режимом, прихватио реторику националног јединства, преговарао са владом иза сцене, избегавао јавну конфронтацију по сваку цену и учврстио своју моћ у цркви.

Виши слојеви Копског друштва су одбацили језик прогона - језик који одликује Коптску средњу класу. Они су подржали партнерство између папе и председника Мубарака које је окарактерисано конзервативизмом и смиривањем - партнерство које служи као препрека испуњењу тежњи коптске средње класе. Као пример ове сарадње издваја се ситуација из 2005. године, Мубарак се тада кандидовао за пети мандат. Имао је подршку цркве и не само то, Шенуда III је позвао Коптске хришћане да гласају за Мубарака и службено је наредио свим бискупима исто (Sedra, 1999). Свети синод је издао службено саопштење о подршци Мубараку. Тај чин био је политички став, а не израз личног мишљења - став који је институционализован на свим нивоима црквене хијерархије и званично је представљао вољу цркве. Коптима је послата порука да они, попут својих верских вођа, треба да подрже Мубарака. Свети Синод је прославио Мубаракову победу тако што су огласили звона на свим црквама у Египту. Употреба ове, чисто верске праксе у изразито политичку функцију замаглила је границе између верских и политичких подручја у Египту тог времена (Sedra, 1999).

Поред блиских односа власти цркве, верски објекти и домови хришћана страдали су и током Мубаракове владавине, само се томе није у великој мери писало и причало. Не постоје тачни подаци колико је Копта убијено последњих деценија или колико је цркава запаљено и потпуно уништено до згаришта. То је од увек била осетљива тема у египатској јавности (Васиљевић, 2016, пара. 8).

\section{ЕТИОПИЈА}

Савезна Демократска Република Етиопија је држава у источној Африци у региону познатом као Рог Африке са популацијом од 100 милиона становника. Етиопској оријентално - православој цркви припада 43,5\% становништва, друга највећа верска група су муслимани (33,9\%), затим протестанти, па католици и припадници традиционалних афричких религи- 
ja. Етиопијска православна црква је једна од најотпорнијих, када су промене у питању. Ова црква, настала из Александријске традиције, успела је да развије своје јединствене карактеристике. Као снажна институција, црква је снажно утицала на политичку, социјалну и културну историју нације (Girma, 2018 према Binns 2016).

Етиопија је једна од древних нација Африке, са дугом политичком и црквеном традицијом. За разлику од Египта, где су муслимани већинско становништво, Етиопија је држава чији су владари тврдили да су директни потомци библијског краља Соломона - последњи монарх Хајле Селасије (Haile Selassie) свргнут је 1974. године од стане марксистичког режима. Етиопијска православна црква била је кључни део система од њеног настанка до данас. Од свог оснивања, руководство Етиопијске цркве било је подељено између две личности: Египатског папе и Етипијског цара. Међутим, цареви интереси су већином били политички, а Коптски папа је представљао далеки ауторитет подложан исламским властима Египта. Као одговор на ову ситуацију монаси су створили мреже децентрализоване организације (Ancel и Ficquet, 2015).

\section{Однос државе и цркве}

Црква је пружила теолошка оправдања за монархичку политичку културу (Girma, 2018 према Abbink 2011). Нове идеје су биле угушене од стране црквених и политичких снага. На крају XX века, црква је била кључна за обједињавање краљевства око заједничког хришћанског идентитета. Питања која се односе на духовне моћи цркве била су кључна за њену трансформацију у том периоду, јер је монархија тежила модернизацији (Ancel и Ficquet, 2015: 63). Током XX века, Етиопијски краљеви имали су за циљ да централизују државу, тј. да наметну своју управу над локалним властима коje су се развијале у XVIII веку. Црква је имала улогу у централизацији државе. Идеја уједињења царства, кроз свештенство и мрежу манастира и жупа преношена је на вернике. Да би до тога дошло било је потребно реорганизовати клер и подвргнути га краљевској моћи. Повезаност са највишим представником цркве омогућавала је владарима спровођење реформи (Ancel и Ficquet, 2015).

Између 1916. и 1930. године млада генерација интелектуалаца и високих званичника тежила је реформи државе. За њих је изградња централизоване државе требало да буде постигнута тако што би црква својим де- 
ловањем створила заједништво засновано на хришћанском идентитету. Поред тога, желели су да црква промовише одлуке државе. То је подразумевало да ће монархија контролисати именовање врховног поглавара етиопијске цркве, који би заузврат имао право да поставља бискупе у покрајинама. Са друге стране, стара конзервативне струје, нису биле вољне да уступе било какве промене у статусу цркве. Осудили су идеју омаловажавања вековне традиције која је спречавала политичко уплитање у чисто црквене афере (Ancel и Ficquet, 2015: 70).

Италијанска окупација Етиопије од 1936. до 1941. зауставила је реформе. Нови владари покушали су одвојити цркву од монархије. У настојању да ослабе везе између Етиопије и Египта, Италијанске власти су покушале да одвоје Етиопијску цркву од Коптске патријаршије. Након што је у почетку сарађивао са окупационом снагом, митрополит се успротивио Италијанском пројекту раздвајања цркава 1937. године, након чега је изабран је нови митрополит. Пређашњи митрополит је описан као незналица која се служила интересима ислама, а његова неспособност да ојача статаус цркве схватана је као намерна завера Копта да ослаби Етиопску цркву. Коптски свети синод прогласио је избор нелегитимним (Ancel и Ficquet, 2015: 72 према Getatchew, 2003).

У Каиру је 1946, године изабран нови папа Коптске црве. Почетком 1951. године изабран је и нови Етиопијски митрополит који је имао право да поставља ниже свештенство које је могло да подржи ефикасну покрајинску управу и утиче тако на вернике. Ово је донело промене у односима између монарха и митрополита. Наиме, новонастале околности, тј.шира аутономија од Коптске цркве била је заслуга напора цара Хајле Селасије. Два догађаја су пресудила дефинитивном одвајању двеју цркава: институционална криза унутар Коптске цркве и Египатска револуција коју је водио Гамал Абдел Насер (Ancel и Ficquet, 2015).

\section{Аутокефалност}

Након смрти Јосифа II (Abba Yousab II) процес избора новог патријарха у Каиру претворио се у сложену дипломатску ситуацију. Епилог је био признавање Етиопијске цркве. Именовање патријарха Етиопије ипак, било је подложно одобрењу Коптског патријарха и Етиопијскиг цара. Постајући аутокефалним, Етиопијска православна црква ушла је у нову фазу у својој историји, нарочито у односу према држави. Ослобођена зависности од 
Коптске цркве, одмах се нашла под надзором монархије (Ancel и Ficquet, 2015).

Монарх је преузео контролу над црквом кроз две паралелне стратегије: Прво је требало добити од Египта право на Етиопијског патријарха и Етиопијске бискупе, друго требало је ставити све жупе и манастире под централизовану власт.

\section{Револуција}

У тренутку када је 1974.године дошло до револуције, црква је имала значајну везу са монархијом. Аграрна реформа резултирала је ударом великих размера на приходе цркве. Влада је укинута власништво цркве над земљом и ослободила сељаке од обавеза плаћања. Црква је тако изгубила сав приход од земљишта, што је представљало највећи део њене економске моћи. Оснивање сељачких удружења задужених за надзор реформи довело је у питање преовлађујући положај свештенства на селу (Ancel и Ficquet, 2015).

Окупљајући чланове клера и лаике у одборе, нове власти су покренуле чистку са циљем борбе против корупције међу црквеним вођама. Чистка је захватила и највише нивое - врховни поглавар Етиопијске цркве, Тевофлос (Abune Tewophilos) оптужен је за корупцију, за чињење неправде током владавине претходног режима и за контакт са контрареволуционарима (Ancel и Ficquet, 2015). Новоизабрани патријарх, Такла Хајманот (Abuna Takla Haymanot) био је „пригодан” тој функцији из угла револуционарног режима. Коптска црква у Египту, на челу са патријархом Шенудом III, оштро је протестовала против његовог именовања и одбила да га призна.

Дух револуције ушао је у цркву, верници су прихватили дискурс нове државе која је промовисала народну демократију и развој. Упркос свом атеизму, Дерг, војна хунте која је дошла на власт након свргавања са власти цаpa, није покушала искоренити православну цркву или ислам, већ се ослањала на верске институције како би ширила своју идеологију и контролисала рурална подручја. Покренут је низ семинара како би се подучило свештенство и верници о компатибилности између принципа социјализма и Библиje. У замену за свој сараднички став, црква је преживела. Чак је дошло и до пораста посећености цркви, јер су људи у ритуалним подручијима нашли уточиште од политичких превирања (Ancel и Ficquet, 2015).

Нови патријарх, изабран 1988. године, Меркориос Зе-Либанос Фанта (Abune Merkorios), остао је изузетно близак режиму, подржавајући Етиоп- 
ско национално јединство и рат против Еритреје. Након што су побуњеничке снаге Револуционарног демократског фронта Етиопијског народа обориле власт 1991. године, нови режим је као и сваки претходни требао подршку цркве. Међутим, црква је била непријатељски настројена (Ancel и Ficquet, 2015).

\section{Патријарх Паулос 1992-2012}

Абуна Паулос (Abune Paulos), изабран је за патријарха 1992. године, а његов предходник Меркориос затворен је и прогнан. Порекло овог патријарха било је недвосмислен показатељ да је власт пружила подршку новој елити, његов избор је представљен као поновно успостављање праведног наследства Абуна Тевофлоса, који је неканонски елиминисан и замењен након револуције. Као жртва злостављања Дерга, нови патријарх изградио је односе и са конзервативним групама.

Неколико изазова било је пред новим патријархом - реорганизација цркве и њене управе морала се догодити у контексту новог политичког оквира и нових духовних тежњи и пракси верника. Упркос међународним вештинама и модерном стилу који је усадио у цркву, ауторитет патријарха Паулоса био је оспораван и ослабљен.

Први значајан чин новог патријарха било је раздвајање етиопијске и еритрејске цркве. Убрзо након референдума о независности Еритреје 1993. године, Еритрејско свештенство је затражило од Коптског патријарха Шенода III да одобри Еритрејцима аутономију од Етиопијске цркве. Иако патријарх није био поборних раскола, успео је да обезбеди мирано одвајање Еритрејске цркве. Од 1959. године Етиопијска православна црква је потпуно пала под контролу државе, па је њен развој неизбежно био повезан са политичким променама (Ancel и Ficquet, 2015: 81).

Поред одвајања Еритрејске цркве, додатна последица промене Етиопијске владе која се одиграла 1992. године била је та да су они прогнаници који су одбацили нову државу створили дисидентску Цркву дијаспоре. Након што је свргнут и замењен, бивши патријарх Меркориос је задржан у притвору, а из земље је успео да побегне 1993. године. Настанио се у САД-у 1997. године, и оформио „правни свети синод у егзилу“, који је брзо преузео контролу над низом Етиопских жупа у иностранству, углавном у Северној Америци, али и у Европи и Аустралији (Ancel и Ficquet, 2015: 82). 


\section{XXI век}

Други изазов који је ослабио положај Етиопијске цркве била је ерозија верника. Године 1994. 50,6\% становништва Етиопије били су верници ове цркве. То је смањено на 43,5\% у 2007. години. Ове промене углавном се објашњавају напретком протестантских цркава евангеличке и пентекосталне цркве (које су у порасту са 10,2 процента становништва у 1994. години на $18,5 \%$ у 2007. години). Жива и брзо растућа сила на југу земље и урбаних средишта, евангеличке цркве надмећу се са Етиопском црквом врбовањем из православних породица, ширењем борбене поруке кроз савремене медије и увођењем нових модела побожности. Муслиманско становништво је остало стабилно (32,4\% у 1994; 34\% у 2007) (Ancel и Ficquet, 2015: 83).

Током двадесет година у којима је Абуна Паулос био патријарх (19922012), Етиопијска црква је претрпела трансформације које су утицале на духовни и друштвени живот верника. Патријархат Паулос био је уско повезан са трансформацијама које је претрпело читаво етиопијско друштво под вођством Мелеса Зенавија (Meles Zenawi). Нова политичка поставка представљала је цркви неколико изазова: одвајање Еритрејске цркве, раскол заједнице дијаспоре и надметање са другим хришћанским деноминацијама на новоотвореном верском „тржишту“. Штавише, након успостављања новог режима, црква је морала да се придржава развојних циљева Мелеса Зенавија. Промене моралних вредности довеле су до критика патријарха.

Изненађујуће, патријарх и премијер су изненада умрли у року од недељу дана током 2012 године. Влада је потврдила свој континуитет потврђивањем Хајлемаријам Десалењ (Hailemariam Desalegn), бившег потпредседника владе, за новог премијера. Први пут у етиопијској историји, протестант је постао шеф државе. У овом периоду председник републике, Гирма Волде Гиоргис (Girma Wolde-Giorgis), покушао је да утиче на патријарху у егзилу да се врати кући. Ова иницијатива је одбачена као противуставно ометање. Покушаји поновног уједињења цркве, међутим, на крају су пропали због одбијања дисидента да признају било којег другог патријарха осим Меркориоса. Абуна Матиас (Abune Mathias) изабран је 2013. године. Представљао је континуитет, његово порекло и међународни профил, врло је сличан предходном патријарху, што указују на то да ће Етиопијска црква и даље бити активан сарадник у националној стратегији развоја Етиопске владе. Након споразума склопљеног 27. јула 2018. године, раније прогнани Меркориос враћен је у службу као ко-патријарх. 


\section{ЕРИТРЕЈА}

Како је Еритреја независност од Етиопије стекла 1993. године, а црква аутокефалност неколико година касније, немогуће је бавити се Еритрејом, а не говорити о Етиопији. Историјски, културно, политички и верски ове две државе су нераскидеве. Еритреја се након стицања самосталности није демократизовала у очекиваној мери, између осталог карактерише је једнопартизам, прогон верника непризнатих религија, али и верника и свештеника признатих религија.

Две најзаступљеније религије су хришћанство и ислам, међутим, број верника је предмет расправе. Већина хришћанског становништва припадници су Еритрејске оријентално-православне цркве, а они су претходно припадали Етиопијско оријентално-православној цркви (Rabasa, 2009). Стејт департмент (U.S. State Department) је 2010. године објавио податке да су 50\% становништва Еритреје хришћани, а око 48\% муслимани (U.S. department of State, 2007, пара 4). Седам година касније, 2017. години процењивало се да је 51,6\% популације Еритреје муслиманске вероисповести, док су хришћани чинили $46,6 \%$. Преосталих $2 \%$ становника практиковало je друге религије, укључујући традиционалне вере и анимизам (Pew research center, 2010). Према трећим изворима, православни хришћани чине 57,7\% становништва Еритреје.

\section{Политичка ситуација}

Еритреја је мултиетничка, вишејезична и мултирелигијска земља, коjа за разлику од Египта нема званичну државну религију. Од независност земље 1991. године, однос државе и религије био је проблематичан. Држава је признала четири религије: ислам, сунитског обреда; еритрејску православну цркву, део светске коптске православне цркве источног обреда; Еритрејску католичка црква, део светског римокатоличког покрета; и Еритрејску евангеличку цркву, део Лутеранске светске федерације. Постоји такође и низ верских веровања која држава формално не признаје. Иако су бројни чиниоци допринели стању у Еритреји, главни проблем је репресивна политичка култура владајуће и једине политичке партије, Народног фронта за демократију и правду. Власт у Еритреји је ауторитарна, непримерена, нестабилна и насилна, а политичко вођство је свемоћно, спремно да учини све што може, по цену основне слободе појединца, како би држав- 
на власт остала нетакнута. Однос државе и религије у таквим условима је проблематичан и постао је главни узрок високог нивоа верског прогона и других облика кршења људских права (Bozzini, 2011).

Религијском плурализму Еритреје приписују се најмање два главна фактора: плуралистичка природа еритрејског друштва које чини најмање девет званично признатих етничких група; и (б) дуга историја колонијализма и трансконтиненталне миграције која потиче из ране историје две најистакнутијих религије у региону: хришћанство и ислам (Mekonnen, 2014).

Током историје Еритреје у различитим односима између државе и религије постојале су различите фазе. Посматрајући историју две најдоминантније религије у Еритреји, хришћанства и ислама, може се оценити однос државе и религије. Кроз историју се православно хришћанство претежно практиковало у висоравни Еритреје у којима су биле настањене древне цивилизације Аксума и касније Абесиније. Као резултат тога, православна црква је увек одржавала врло присан однос са владајућом класом, посебно са краљевима и царевима Абесиније. Ова дуга историја снажне везе између православне цркве и државе додатно је ојачана средином XX века, што се може видети из следећег: „Средином XX века, православна црква формално се ускладила са монархијом под Јоханесом IV (Yohannes IV). Тада је започето „божанско виђење“ царева (Mekonnen и Selam, 2014). Договор цркве и државе учврстио је културну, политичку и религиозну доминацију планинских народа, окружену страхујућом муслиманском периферијом. Регионална, економска и верска подела царства на православне хришћане и муслимане карактерисала је и Етиопиjу, као и северну провинцију Еритреју“ (Mekonnen и Selam, 2014 према Hepner, 2003). У поређењу са другим релиигијама, у овом периоду првославна црква имала је велики утицај - статус православне цркве био је еквивалентан државној религији, посебно у висоравни Абесиније. Иако хришћанство никада није било државна религија однос између православне црве и владајуће класе (монарха) били су врло блиски. Цар старе Абесинске државе морао је бити хришћанин и сматран је ,заштитником“ цркве. До пада посљедњег етиопског цара, Хајле Селасије I, 1974. године идеолошки оквир државе био је уоквирен према теолошкој конструкцији православне цркве (Mekonnen и Selam, 2014). 


\section{Независност}

Принцип раздвајања државе и религије постоји само у закону, у пракси је овај принцип постао жртва свеприсутног непоштовања владавине права. Влада се уплиће у верске послове изван онога што се може описати као пожељана интервенција, чиме Еритреја постаје једна од најгорих држава у погледу верских слобода. У годишњем извештају Министарства спољних послова САД-а о верским слободама, Еритреја се обично спомиње на врху листе кршилаца верских права (U.S. Department of State International Religious Freedom Report, 2011). У многим другим међународним истраживањима која мере заштиту основних права, Еритреја се такмичи за последње место са тако озлоглашеним земљама као што су Северна Кореја и Туркменистан (Mekonnen и Selam, 2014).

Еритреја је током највећег дела своје историје идентификована као место верске толеранције и прихватања свих верских заједница као једнако валидних. Генерално посматрано, однос између еритрејских верских заједница претежно је био компромис. То у одређеној мери важи и за однос државе и религије, што је био темељ за дугу историју суживота. У доба после независности, између 1991. и 1998. године, делом су се поштовала основна права и слободе, попут слободе вероисповести и богослужења. Међутим, то не значи да тада није било случајева верског прогона. Криза верског прогона врхунац је досегла 2002. године, када је влада наредила укидање појединих верских група.

\section{Патријарх Антонио}

Током периода Италијанске колонијалне власти основана је Еритрејска православна црква, као огранак Етиопијске оријентално - православне цркве. Намера им је била да умање утицај Етиопије у Еритреји. Након повлачења Италије 1936. године са ових простора дошло је до уједињења цркава. Стицања независности дошло је до коначног разлаза са Коптском црквом. Коптски папа Шенуда III 1998. године је именовао епископа Филипоca (Abune Phillipos) за првог патријарха Еритрејске православне тевахедо цркве признајући јој аутокефалност, што је признала и Етиопијска оријентално-православна црква.

После смрти абуна Филипоса 2001. године, прво је изабран абуна Јакоб (Abune Yacob) за патријарха, а затим абун Антонио (Abune Antonios) 2004. 
године. Као Патријарх Еритреје бунио се против већег мешања владе у верске послове. Његови захтеви да влада треба да ослободи утамничене хришћане који су оптужени за издају, сматрају се једним од разлога за његов сукоб са Еритрејским властима. Свети Синод је стао на страну владе и током јануара 2005. године одржана је тајна седница на којој су патријарха лишили извршне власти. Свети Синод је тражио подршку папе Шенуде III да уклони Абуну Антонија, али је он одбио да подржи такав чин (Aleksander, 2018, пара. 4). Тајно заседање Светог Синода 2006. довело је до званичног уклањања са трона патријарха. Кршећи црквене каноне и устав, влада је поставила епископа Диоскороса (Abune Diosqoros) за антипатријарха 2007. године. Абуна Антоније је био присиљен да напусти своју службу и затворен је на непознатој локацији (Aleksander, 2018, пара.5) Октобра 2017. године влада је обманула међународну заједницу организујући састанак помирења и литургијску службу. Патријарх Абуна Антоније је учествовао у служби. Ниједна изјава није добијена од њега. Тим поводом прочитано је званично саопштење, али оригинални састав писма је различит од онога што је договорено између Патријарха и власти. Фотографије патријарха Абуне Антонија који присуствује Божанској Литургији објављене су на друштвеним мрежама и притом истиче да су окончани проблеми између патријарха Абуна Антонија и Светог Синода Еритрејске Цркве. Међутим, после те литургије патријарх је склоњен на непознату локацију, а његово затварање и даље збуњује хришћански свет.

Упркос томе што је једна од званично признатих и највећих хришћанских заједница у Еритреји, влада прогони православну цркву. Према извештају организације In chains for Christ ${ }^{1}$, 2005. године, 1500 православних свештеника и ђакона је присиљено је да служи војску, чиме се црква лишава свештенства. Процењује се да ће више од 1500 православних цркава бити затворено у догледној будућности. Током протекле четири године Православна Црква се свела на продужену руку одељења верских послова. Историјски и древни артефакти Православне Цркве уклоњени су из цркава и манастира и конфисковани су од стране владе (Aleksander, 2018, пара. 9).

1 https://www.inchainsforchrist.org/ 


\section{Закључак}

Историја нам је показала да је спрега религије и политике довела до институционализпвања политичких система са доминантном религијом у којима ограничено делвање свим другим религијама (Јевтић, 2009).

Хришћанска популација у Египту поистовећује се са Коптском црквом, припадност овој верској групи одређује и национални идентитет. Као представници Коптске нације издвојиле су се верске вође, које у име својих верника преговарају о њиховом положају у држави. Из свега представљеног у раду евидентно је да је ова хришћанска мањина кроз XX век зависила искључиво од односа председника са Александријским папом, сав политички ангажман им је ускраћем, а црква се позиционирала као представник Копта. Једна верска институција једини је представник више од 10\% становника који преговара о њиховој судбини. То нам показује са су Копти у Египту, чак и у XXI веку далеко од секуларизације, а да је носилац свих политичких процеса њихоце заједнице - црква. Након Арапског пролећа положај Копта се погрошао, али то не значи да је већинско муслиманско стаовништво ранијих деценија благонаклоно гледало на хришћанску мањину на територији муслиманског Египта. Ислам је религија која не одваја верско од световног и која пропагира слободу дефинише као слободу да се живи у складу са Кураном. То је суштински разлог сукоба муслимана са немуслиманским станвништвом у исламским земљама - то становништво представља препреку остваривања исламског права.

Етиопија је држава чији су владари тврдили да су директни потомци библијског краља Соломона, те је црква одувек била кључни део система. Управо су теолошка оправдања за монархичку политичку културу и гушење нових идеја долазили из цркве. На крају XX века, одиграла је кључну за обједињавање краљевства око заједничког хришћанског идентитета. Свакако да су у Етиопији, као и у Египту, блиске везе са највишим представником цркве омогућавале владарима спровођење реформи, јер су се власти користиле црквом као каналом којим су допирали до грађана. Након револуције нове власти су покренуле чистку међу црквеним вођама. Упркос свом атеизму, нису покушали искоренити религију, већ су верске институције користили за ширење своје идеологије.

Релативно изједначен број муслимана и хришћана у Еритреји не изазива значајне верске сукобе, јер су последнице једнопартијске диктартуре централни проблем ове државе. Како је приказано, верске слободе у Еритреји 
су веома ограничене, али то не значи да држава не користи цркву као средтво за остварење циљева. Директно мешање у избор патријарха и контрола његовог рада показују колико је властима битно да утичу и усмеравају верске институције.

Ове три државе - Египат, који чини 90\% муслимана, Етиопија са већинском хришћанском популацијом и Еритреја у којој је број муслимана и хришћана изједначен пример су колико владајуће структуре у савременим Афричким државама теже да одржавају контакте са верским групама, са утичу на њих и у екстремним ситуацијама да их контролишу и експлоатишу.

\section{Литература}

Александер Џорџ (2018), Проїоњени хришћани и Црква на изgисају у Еритиреји, Доступно на: http://spc.rs/sr/progonjeni_hrishtshani_crkva_na_izdisaju_u_eritreji (Приступљено: 25.2.2020)

Васиљевић Кумер Леа (2016), Еїийаисски и истиочни хришћани gанас у Политика, 20.12.2016. Доступно на: shorturl.at/gtB36 (Приступљено: 25.2.2020)

Јакшић Бошко (2013), Гневни исламисиии ировоне Койие у Политика: 20.08.2013, Доступно на: shorturl.at/ouBRT (Приступљено: 25.2.2020)

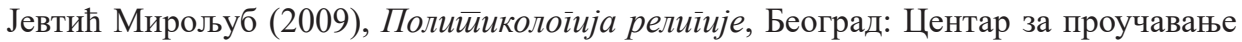
религије и верску тореланцију

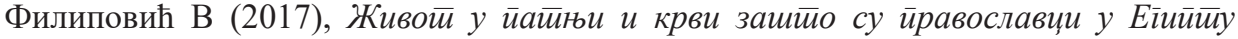
вековима на метии екситремистиа? у Блиц, 11.4.2017. Доступно на: shorturl.at/ FHLU0 (Приступљено: 25.2.2020)

Ancel Stéphane i Ficquet Éloi (2015), The ethiopian orthodox tewahedo church (eotc) and the challenges of modernity u Understanding Contemporary Ethiopia: Monarchy, Revolution and the Legacy of Meles Zenawi, London: Hurst, 63-91

Bozzini David (2011), Low-tech surveillance and the despotic state in Eritrea $y$ Surveillance \& Society бp. 9, cūp. 93-113

Girma, Mohammed (2018), Religion, politics and the dilemma of modernising Ethiopia $y$ HTS Teologiese Studies/Theological Studies, vol.74. бp.1

Hanna Michael Wahid (2019), Excluded and Unequal u Citizenship and Its Discontents: The Struggle for Rights, Pluralism, and Inclusion in the Middle East, New York: The Century Foundation

Paul Sedra (1999) Class cleavages and ethnic conflict: Coptic Christian communities in modern Egyptian politics, Islam and Christian-Muslim Relations, cūp: 219-235

Pew research center (2010), Global Christianity, Dostupno na: shorturl.at/IFOR5 (Пристиуйьено: 25.2.2020)

Rabasa Angel (2009), Radical islam in east Africa, Santa Monica: Rand

US department of State (2007), International religious freedom report,Bureau of democracy, human rights, and labor, Доступно на: https://web.archive.org/ 
web/20180709215605/https://www.state.gov/j/drl/rls/irf/2007/90096.htm (Присииуйьено: 25.2.2020)

US Department of State International Religious Freedom Report (2011), Доступно на: https://2009-2017.state.gov/j/drl/rls/irf/2011/af/192709.htm (Прист̄: 25.2.2020)

World population review (2020), Доступно на: http://worldpopulationreview.com/countries/egypt-population/ (Присииуйьено: 25.2.2020)

Mekonnen Daniel i Kidane Selam (2014), The troubled relationship of state and religion in Eritrea $u$ African human rights law journal $б p .1$, Southern African Legal Information Institute

\title{
Milica Škorić
}

University of Belgrade

Faculty for Political Sciences

milica95.skoric@gmail.com

\section{THE ROLE OF RELIGION IN THE POLITICAL PROCESSES OF EGYPT, ERITREA, AND ETHIOPIA IN THE XX AND XXI CENTURY}

\begin{abstract}
Summary
Although secularization is the principle of most countries today, in this paper in the example of Egypt, Eritrea, and Ethiopia, we will show the connection of the religious community of Oriental-Christian Christians with the authorities of the selected states. The Church has been exploited for decades in these countries for political goals, reforms, ideas of revolution, etc. This paper, among other things is exploring status of copts and divisions in understanding their identities. Religious leaders relations with the authorities in the XX and XXI century have been a central point of work. The example of secession of Eritrea from Ethiopia, which was followed by the separation of the church, proved that independent church in independent state is important element in controlling the masses and directing citizens in the desired direction. To a large extent, the paper is based on explaining the political situation in the elected states and the place of the church in those periods. It has been shown that the church often followed the authorities for the sake of survival and peace, but opposite examples are known too. The fates of these chiefs were often death, exile, or imprisonment.
\end{abstract}

Keywords: Egypt, Eritrea, Ethiopia, Copts, Monophysites, Oriental-Orthodox Churches, Christianity, Islam, Secularization, Religion, Africa 